\title{
TELAAH KOMPARATIF PENGARUSUTAMAAN GENDER \\ DALAM PENDIDIKAN ISLAM DI SAUDI ARABIA, MESIR, MALAYSIA, DAN INDONESIA
}

\author{
Rohil Zilfa \\ (STIT Jembrana Bali)
}

\begin{abstract}
Abstrak:
Artikel ini menganalisis pengarusutamaan gender ditinjau dari perspektif perbandingan pendidikan bagi perempuan di beberapa negara Asia dan Afrika, di mana kondisinya memiliki persamaan dalam konstruksi sosiokultur, dan pengaruh interpretasi keagamaan yang dijadikan instrumen legitimasi superioritas laki-laki sangat tampak. Hal ini mempengaruhi ruang gerak perempuan pada wilayah publik, termasuk hak untuk meraih pendidikan yang lebih tinggi. Penelitian ini adalah analisis komparatif tentang konstruksi sosial tentang perbedaan gender yang melahirkan ketidakadilan (gender inequalities) di Indonesia, Malaysia, Mesir dan Saudi Arabia. Hasil dari penelitian ini menunjukkan bahwa mulanya di beberapa negara di Asia (termasuk Indonesia) masih terjadi domestifikasi dan subordinasi pada perempuan, yang mana hal tersebut dibatasi dengan interpretasi agama yang selektif dan tradisional, sehingga mereka tidak mudah mengenyam pendidikan. Namun, dalam perkembangannya, terjadi peningkatan dalam keterlibatan perempuan di bidang pendidikan melalui pengarusutamaan gender oleh pemerintah dalam mengembangkan sumber daya manusia di beberapa negara tersebut. Regulasi-regulasi yang telah ditetapkan menunjukkan keseriusan pemerintah dalam masalah ketidaksetaraan gender yang terjadi. Pengarusutamaan gender merupakan bagian dari strategi pembangunan manusia yang terkorelasi dengan pendidikan Islam. Di Indonesia, hal yang menjadi perhatian Menteri Negara Pemberdayaan Perempuan dan Perlindungan Anak Republik Indonesia adalah dengan menetapkan Peraturan Menteri Negara Pemberdayaan Perempuan dan Perlindungan Anak Republik Indonesia Nomor 11 Tahun 2010 tentang Pedoman Pelaksanaan Pengarusutamaan Gender di Madrasah.
\end{abstract}

Kata Kunci: Pengarusutamaan; Gender; Pendidikan; Islam; Perempuan. 


\begin{abstract}
:
This article examines gender-mainstreaming effort from a perspective of comparative women education in several Asian and African countries, in which the countries have common socioculture condition and religious interpretation positioning male superiority over female. This situation affects female's roles in public sphere, including female's rights in pursuing higher degree of education. This study comparatively analyzes social contruction giving birth to gender inequalities in Indonesia, Malaysia, Egypt, and Saudi Arabia. The result of this study indicates several Asian countries (including Indonesia), at the beginning, experienced domestification and subordination of women due to traditional and selective religious interpretation, resulting difficulties to access to education for women. However, in its development, women has been increasingly involved in education through gender mainstreaming efforts by governments in order to develop human capacity in the countries. Several regulations indicates government's serious efforts in solving the gender inequalities issues. This gender mainstreaming effort has become a part of human development strategy intergrated in Islamic education. In Indonesia, this issue got attention from Minister of Women Empowerment and Children Protection by issuing Ministry regulation No 11 of year 2010 regarding the Principality of Gender Mainstreaming in Madrasah.
\end{abstract}

\title{
Keywords: Mainstreaming; Gender; Education; Islam; Women.
}

\section{A. Pendahuluan}

Pengarusutamaan gender menjadi isu global sebagai strategi sistematis yang digalakkan oleh berbagai negara di penjuru dunia untuk mencapai kesetaraan gender. Hal ini berkaitan dengan kualitas sumber daya manusia setiap bangsa, mengingat ketimpangan gender yang melanda berbagai negara yang menjadi salah satu permasalahan dalam pembangunan bangsa serta menjadi hal mendasar dalam human right (Hak Asasi Manusia) yang menjadi perhatian seluruh bangsa.

Berbicara mengenai gender bukanlah diskursus yang baru diperbincangkan oleh berbagai kalangan. Karena sejak dua dasa warsa terakhir telah menjadi pokok bahasan dalam wacana mengenai perubahan sosial serta menjadi topik penting dalam setiap perbincangan mengenai pembangunan. Gender merupakan konsep sosial yang membedakan peran laki-laki dan perempuan, Namun dalam masyarakat terjadi miss understanding mengenai perbedaan tersebut, bahkan membias dalam kehidupan masyarakat sehingga terjadi berbagai ketidak-setaraan dan ketidakadilan. Terbentuknya perbedaan gender dikarenakan oleh banyak hal di antaranya dibentuk, disosialisasikan, diperkuat, bahkan dikonstruksi secara sosial atau kultural melalui ajaran 
keagamaan maupun regulasi pemerintah suatu negara. Melalui proses panjang, sosialisasi gender tersebut akhirnya dianggap seolah-olah ketentuan Tuhan.

Konstruski sosial tentang perbedaan gender melahirkan ketidakadilan (gender inequalities) baik bagi kaum laki-laki dan terutama bagi perempuan. Faktor yang menyebabkan ketidakadilan atau ketidakseimbangan gender adalah akibat adanya gender yang dikonstruksikan secara sosial dan budaya. Berbagai ketidakadilan (gender inequalities) terjadi dalam masyarakat yang seolah-olah sulit untuk dirubah, karena dikonstruksi oleh budaya yang ditanamkan sejak dini sehingga mengakar dalam kehidupan masyarakat.

Ketidakadilan gender meliputi: pertama, diskriminasi, kedua, subordinasi, dan ketiga stereotip, keempat kekerasan (violence), kelima beban kerja lebih berat. Kelima hal tersbut menjadi perhatian dalam memecahkan permasalahan yang dihadapi oleh kaum perempuan di berbagai negara. Termasuk dalam hal ini adalah yang berkaitan dengan kesempatan belajar atau berkaitan dengan pendidikan bagi perempuan di berbagai negara. Masalah ini termasuk kategori diskriminasi. Merujuk pada pengertian diskriminasi disadur dari bahasa Inggris discrimination adalah perlakuan berbeda terhadap seseorang ataupun kelompok.

Dalam hal ini diskriminasi perempuan juga dialami pada aspek pendidikan, yang jika ditelisik dalam esensi ajaran agama manapun tidak membenarkan hal tersebut. Apalagi dalam esensi ajaran Islam yang sangat memuliakan posisi perempuan. Namun tidak jarang dijumpai terjadinya diskriminasi di negara yang berpenduduk mayoritas Islam. Evaluasi kondisi ini seharusnya memiliki porsi yang proporsional sehingga diskriminasi dapat diminimalisir sekecil mungkin, seperti di negara tetangga Singapura yang index ketidaksetaraan gender $0.088 .{ }^{1}$

Permasalahan inequality gender yang melanda berbagai negara menjadi perhatian dunia, hal tersebut tampak pada keseriusan berbagai negara dalam meminimalisir ketidakadilan tersebut, termasuk yang paling urgen dalam kehidupan masa depan perempuan adalah bidang pendidikan. Oleh karena itu, konsep kesetaraan gender selalu mengemuka. Menurut Evi Fatimatur Rusdiyah, kesetaraan gender menjadi konsep analisis yang digunakan untuk mengidentifikasi peran, relasi, atribut, peringkat, karakteristik, serta perbedaan antara laki-laki dan perempuan dalam rangka menempatkan posisi setara antara

1 UNDP, "Human Development Index Report, Gender Inequality Index 2014", dalam http://hdr.undp.org. Diakses pada 23 September 2017.

Jurnal Pendidikan Agama Islam (Journal of Islamic Education Studies)

Volume 5 Nomor 2 (2017)

ISSN(p) 2089-1946\& ISSN(e) 2527-4511

Hal. 266 - 287 
laki-laki dan perempuan untuk mewujudkan tatanan sosial masyarakat yang lebih egaliter. ${ }^{2}$

Setiap negara memiliki ideologi yang menyertai berkembang atau tidaknya kesetaraan gender yang secara sadar dikonstruksi secara kultural sehingga memiliki implikasi besar terhadap pendidikan perempuan. Kesetaraan gender dalam pendidikan bermula sekitar tahun 1993 sampai hari ini. ${ }^{3}$ Namun perjuangan awal telah dimulai oleh gelombang pertama feminisme yang dilakukan oleh Mary Wollstonecraft agar perempuan mendapat akses pendidikan. Secara kongkret, Mary mendirikan sekolah khusus untuk perempuan di Newington Green, London bagian Utara. 4

Dalam konteks historis, ketidaksetaraan gender antara laki-laki dan perempuan terjadi melalui proses yang sangat panjang. Oleh karena itu, terbentuknya ketidaksetaraan gender disebabkan oleh banyak hal, diantaranya adalah dibentuk, disosialisasikan, diperkuat, bahkan dikonstruksi secara sosial dan kultural melalui ajaran keagamaan maupun negara. ${ }^{5}$ Melalui proses panjang tersebut, akhirnya mengkristal menjadi dogma yang dianggap ketentuan Tuhan seolah-olah bersifat biologis yang tak bisa diubah lagi, sehingga perbedaan gender dianggap dan dipahami sebagai kodrat laki-laki dan kodrat perempuan.

Ketidaksetaraan gender ternyata memunculkan perbedaan peran gender (gender roles) yang akhirnya melahirkan ketidakadilan gender (gender inequalities). Identifikasi bahwa laki-laki itu kuat dan rasional telah menimbulkan kesan bahwa dia lebih cocok untuk bekerja di luar rumah, pantas untuk memimpin dan lain-lain. Sebaliknya, pandangan bahwa perempuan itu lemah lembut atau sabar telah memunculkan anggapan bahwa perempuan cocok untuk tinggal di rumah mengurus anak-anak dan rumah tangga. Inilah sumber yang diduga menjadi penyebab lahirnya ketidakadilan hubungan laki-laki dan perempuan. ${ }^{6}$

Di sisi lain, permasalahan ketidaksetaraan gender juga terkait dengan beberapa hal, seperti kepemimpinan, akses pendidikan, pekerjaan, dan juga

2 Lihat Evi Fatimatur Rusydiyah, "Pendidikan Islam dan Kesetaraan Gender (Konsepsi Sosial tentang Keadilan Beerpendidikan dalam Keluarga," Jurnal Pendidikan Agama Islam (Jornal of Islamic Education Studies), Vol. 4 No. 1 (2016).

3 Shailaja Fennell and Madeleine Arnot, Gender Education and Equality in Global Context; Conceptual Framework And Policy Perspective (London and New York: Routledge, 2007), 18.

4 Akhyar Yusuf Lubis, Pemikiran Kritis Kontemporer; Dari Teori Kritis, Culture Studies, Feminisme, Postkolonial Hingga Multikulturalisme (Jakarta: Rajawali Pers, 2015), 97.

5 Baca Mansour Faqih, Analisis Jender dan Transformasi Sosial (Yogyakarta: Pustaka Pelajar, 1999), 9.

6 Bani Syarif Maula, "Kepemimpinan dalam Keluarga: Perspektif Fiqh dan Analisis Gender," Musawa; Jurnal Studi Gender dan Islam, Vol. 3, No. 1, (Maret 2004). 
pendidikan. Tulisan ini fokus berbicara mengenai akses pendidikan, yakni kesempatan untuk mengenyam pendidikan yang lebih tinggi, juga proses pembelajaran yang masih ada kesenjangan gender di dalamnya, termasuk pula materi pelajaran. Permasalahan di atas bahkan menjadi program utama UNESCO dalam tujuan program pendidikannya untuk meningkatkan kesetaraan gender menyeluruh dalam sistem pendidikan: partisipasi pada akses pendidikan, isi, pembelajaran, praktiknya, penyampaian model serta tugas-tugasnya. ${ }^{7}$ Oleh sebab itu, penting untuk memahami pengarusutamaan gender dalam bidang pendidikan di beberapa negara, seperti Arab Saudi yang secara genealogis adalah tanah kelahiran Islam, dan juga negara lain sepertiIndonesia, Mesir dan Malaysia.

\section{B. Prinsip-prinsip Kesetaraan Gender dalam Islam}

Cita-cita al-Qur'an sebagai teks keagamaan adalah tegaknya kehidupan manusia yang bermoral luhur dan menghargai nilai-nilai kemanusiaan universal (humanisme universal). Muhammad Husein memaparkan, bahwa prinsip-prinsip kemanusiaan universal itu antara lain diwujudkan dalam upaya-upaya penegakan keadilan, kesetaraan, kebersamaan, kebebasan, dan penghargaan terhadap hak-hak orang lain, siapa pun dia. Prinsip-prinsip tersebut harusnya dijadikan dasar ketika melakukan kajian terhadap ayat-ayat al-Qur'an. Demikian pula dalam penafsirannya. ${ }^{8}$

Dalam hal ini Al-Qur'an secara tegas menyatakan bahwa kaum perempuan memiliki hak yang sama dengan kaum laki-laki. Sebagaimana lakilaki memiliki hak atas perempuan, perempuan memiliki hak atas kaum laki-laki. Sebagaimana perempuan memiliki kewajiban terhadap laki-laki, laki-lakipun memiliki kewajiban terhadap perempuan. ${ }^{9}$ Oleh karena itu, Islam mengangkat mereka ke status yang layak sebagai manusia yang bermartabat sebagaimana laki-laki. Untuk selanjutnya laki-laki dan wanita dipandang sejajar dari segi kemanusiaannya.

Prinsip kesetaraan gender dapat diidentifikasi bahwa derajat manusia tidak menjadi wilayah kaum laki-laki saja, karena perempuan juga memiliki kapasitas untuk mengakses derajat tersebut. Ada beberapa alasan untuk mengenai hal tersebut, di antaranya: Pertama, Al-Qur'an memberikan tempat yang sangat tinggi terhadap seluruh manusia yang mencakup laki-laki dan perempuan. Kedua, sebagai masalah norma, Al-Qur'an membela prinsip

\footnotetext{
7 UNESCO, "Promise Gender Equality - A Global Priority, The Division for Gender Equality", 8, dalam http://www.unesco.org/genderequality. Diakses pada 15 Agustus 2017.

${ }^{8}$ Husein Muhammad, Fiqh Perempuan (Yogyakarta: LKiS, 2001), 18.

9 Zaitunah Subhan, Tafsir Kebencian: Studi Bias Gender dalam Tafsir Al-Qur'an (Yogyakarta: LKIS, 1999), 133.
} 
kesetaraan antara laki-laki dan perempuan. Perbedaan biologis tidak berarti ketidaksetaraan dalam status jenis kelamin. Fungsi-fungsi biologis harus dibedakan dari fungsi-fungsi sosial.

Secara lebih deskriptif, Amina Wadud, menjelaskan bahwa setiap individu (manusia) memiliki nilai yang secara inheren sama baik laki-laki maupun perempuan. Perbedaan merupakan sunnatullah yang idealnya membawa pada rahmah. Sehingga tidak ada konsep tentang perempuan dalam al-Qur'an, juga sebaliknya, tidak ada konsep yang bernuansa gender. Kesetaraan tersebut meliputi beberapa hal, yakni: ${ }^{10}$

Pertama, dalam hal penciptaan manusia, al-Qur'an menekankan kesatuan asal seluruh umat manusia. Kedua, terkait dengan perkembangan di dunia, alQur'an menegaskan bahwa potensi untuk berubah, tumbuh, dan berkembang ada dalam nafs individu (atau kelompok juga). Ketiga, semua aktivitas manusia diberi balasan berdasarkan apa yang telah diupayakan. Secara normative, hal tersebut tercantum dalam al-Qur'an surat Ali Imron ayat 195, yang di dalam tafsir alMaraghi pada kesimpulan ayatnya dijelaskan bahwa laki-laki dan perempuan sama di hadapan Allah dalam hal pembalasan. Allah menjelaskan 'illat persamaan ini adalah redaksi ba'dhukum min ba'dh. ${ }^{11}$ Sedangkan dalam tafsir alQasi disebutkan bahwa redaksi ba'dhukum min ba'dh artinya laki-laki dari perempuan, dan perempuan dari laki-laki, yang mana semuanya adalah manusia. Jadi jelas tidak ada yang dominan, keduanya setara. ${ }^{12}$

Ketiga hal di atas menunjukkan kesetaraan antara laki-laki dan perempuan. Namun masih banyak pemahaman yang telah mendarah daging dalam masyarakat Muslim yang masih memposisikan perempuan pada posisis inferior. Hal itu tidak bisa dipungkiri. Di antara penyebab dari ketidaksetaraan menurut Wadud yang memunculkan ketidakadilan adalah penafsiran yang memperlakukan jawaban al-Qur'an terhadap persoalan-persoalan spesifik sebagai jawaban yang bersifat universal,13 yang diyakini oleh Barlas bahwa keengganan untuk membedakan hal-hal universal dengan yang spesifik dalam alQu'an bermula dari rumusan para mufassir tentang teori hubungan antara wahyu (sakral/ universal dan penafsirannya (spesifik/ historis) dan pemilihan hadith misoginis serta penyebarannya yang mengalahkan hadith-hadith yang sensitif gender.

\footnotetext{
10 Amina Wadud, Qur'an Menurut Perempuan: Membaca Kembali Kitab Suci dengan Semangat Keadilan. Terj. Abdullah Ali (Jakarta: Serambi Ilmu Semesta, 2006), 68.

${ }^{11}$ Ahmad Musthofa al-Maraghi, Tafsir al-Maraghi, Juz 4.

12 Muhammad Jamaludddin al-Qasi, Tafsir al-Qasi (Darul Kutub al-Ilmiyyah: Beirut), Juz 2, 484.

${ }^{13}$ Al-Qasi, Tafsir al-Qasi, 114.
} 
Sesuatu yang seringkali disalahpahami (terjadi misunderstanding) adalah keyakinan bahwa interpretasi (tafsir) bukanlah wahyu, namun produk pemikiran manusia yang tidak terlepas dengan kondisi sosiokultur para penafsir saat itu. Menurut Arkoun, ${ }^{14}$ bahasa, nalar dan sejarah memiliki hubungan yang menjadikan pembaca mampu memahami sebab-sebab yang tersebar sebagai petunjuk untuk mengungkap peristiwa di balik turunnya ayat yang selama ini seringkali diabaikan, terutama melalui pendekatan antropologis yang menurut Arkoun al-Qur'an banyak membicarakan tentang manusia. Jadi jelas keterkaitan antara aspek sejarah dengan pemikiran, yang dalam hal ini adalah bagian dari produk manusia yang bersifat relatif serta tidak absolut kebenarannya, sehingga perlu dikontekstualisasikan sesuai dengan kondisi saat ini.

Dalam hal ketidaksetaraan gender banyak ditemukan pada penafsiran ulama-ulama klasik, misalnya, pada ayat al-Qur'an dan Hadith menurut penafsiran ulama dahulu mengatkan bahwa kaum perempuan tercipta dari dan untuk pria. ${ }^{15}$ Seperti ayat al-Qur'an surat an-Nisa' ayat 1:

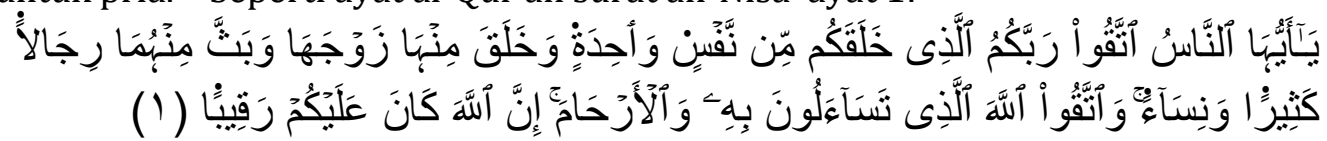

"Hai sekalian manusia, bertakwalah kepada Tuhan-mu yang telah menciptakan kamu dari seorang diri, dan dari padanya ${ }^{16}$ Allah menciptakan isterinya; dan dari pada keduanya Allah memperkembang biakkan laki-laki dan perempuan yang banyak. dan bertakwalah kepada Allah yang dengan (mempergunakan) namaNya kamu saling meminta satu sama lain,17 dan (peliharalah) hubungan silaturrahim. Sesungguhnya Allah selalu menjaga dan mengawasi kamu."

Ayat yang lain yakni surat al-A'raf ayat 189:
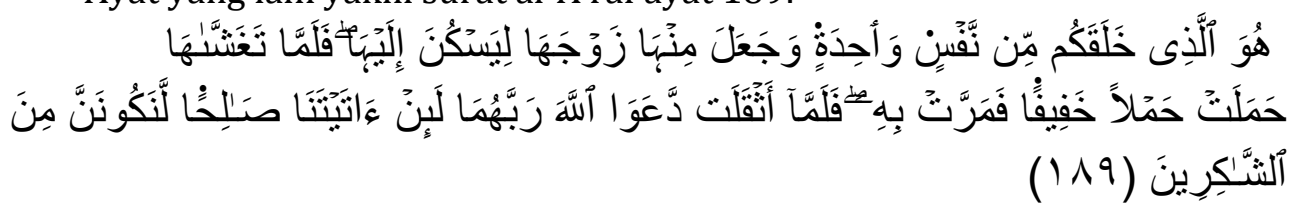

${ }^{14}$ Muhammad Arkoun, Tarikhiyyah Al-Fikr Al-'Araby Al-Islamy, Terj. Hasyim Sholeh (Beirut: Markaz Al-Inma' Al-Qaumi, 1998), Cet III, 8.

15 Baca Sekapur Sirih Ratna Megawangi dalam Sachiko Murata, The Tao of Islam: Kitab Rujukan tentang Relasi Gender dalam Kosmologi dan Teologi Islam, Terj. Rahmani Astuti dan M. S. Nasrullah (Bandung: Mizan, 1996), 11.

16 Maksud dari padanya menurut jumhur mufassirin ialah dari bagian tubuh (tulang rusuk) Adam a.s. berdasarkan hadis riwayat Bukhari dan Muslim. di samping itu ada pula yang menafsirkan dari padanya ialah dari unsur yang serupa Yakni tanah yang dari padanya Adam a.s. diciptakan.

17 Menurut kebiasaan orang Arab, apabila mereka menanyakan sesuatu atau memintanya kepada orang lain mereka mengucapkan nama Allah seperti :As aluka billah artinya saya bertanya atau meminta kepadamu dengan nama Allah.

Jurnal Pendidikan Agama Islam (Journal of Islamic Education Studies)

Volume 5 Nomor 2 (2017)

ISSN(p) 2089-1946\& ISSN(e) 2527-4511

Hal. 270 - 287 
"Dialah yang menciptakan kamu dari diri yang satu dan dari padanya Dia menciptakan isterinya, agar Dia merasa senang kepadanya. Maka setelah dicampurinya, isterinya itu mengandung kandungan yang ringan, dan teruslah Dia merasa ringan (Beberapa waktu). kemudian tatkala Dia merasa berat, keduanya (suami-isteri) bermohon kepada Allah, Tuhannya seraya berkata: "Sesungguhnya jika Engkau memberi Kami anak yang saleh, tentulah Kami terraasuk orang-orang yang bersyukur".

Ayat al-Qur'an tersebut yang dijadikan kekuatan oleh laki-laki sebagai landasan atas superioritas mereka terhadap inferioritas perempuan. Padahal, menurut Ratna Megawangi, jika dikaji secara mendalam, di luar tataran lahiriah yang relatif, segala sesuatunya pasti terkait dengan penciptaan kosmos, dan pasti ada maknanya. ${ }^{18}$ Hal ini sangat ironi, jika dikuantifikasikan hadith-hadith yang misoginis jauh lebih sedikit (hanya sekitar enam hadith yang dianggap shahih) dari sekitar 70.000 hadith dibandingkan hadith yang sensitif gender. ${ }^{19}$ Namun beberapa hadith misoginis dijadikan legitimasi untuk menegaskan ketidaksetaraan gender serta mengabaikan yang bernuansa kesetaran gender. ${ }^{20}$

Maka, harus ada reinterpretasi teks al Qur'an yang menegaskan bahwa Islam juga mengangkat laki-laki dan perempuan ke status yang layak sebagai manusia yang bermartabat sebagaimana laki-laki. Untuk selanjutnya, laki-laki dan wanita dipandang sejajar dari segi kemanusiaannya. Dalam al-Qur'an surat al-Hujurat ayat 13 dijelaskan:

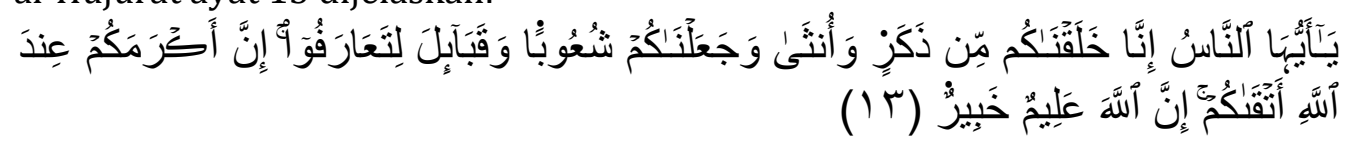

"Hai manusia, sesungguhnya Kami menciptakan kamu dari seorang laki-laki dan seorang perempuan dan menjadikan kamu berbangsa-bangsa dan bersuku-suku supaya kamu saling kenal mengenal. Sesungguhnya orang yang paling mulia diantara kamu disisi Allah ialah orang yang paling bertaqwa diantara kamu. Sesungguhnya Allah Maha Mengetahui lagi Maha Mengenal." (QS. Al-Hujurat: 13).

Berdasarkan ayat tersebut, prinsip kesetaraan antara perempuan dan laki-laki ini dapat dilihat. Islam mengajarkan bahwa derajat al-insa $>n$ al- kami $>l$ (manusia sempurna) tidak menjadi wilayah kaum laki-laki saja, karena perempuan juga memiliki kapasitas untuk mengakses derajat tersebut. Islam memberikan tempat yang sangat tinggi terhadap seluruh manusia yang

18 Megawangi dalam Sachiko Murata, The Tao of Islam, 11.

${ }^{20}$ Asma Barlas, Cara Qu'ran Membebaskan Perempuan (Jakarta: Serambi Ilmu Semesta, 2005), 108. 
mencakup laki-laki dan perempuan. Al-Qur'an membela prinsip kesetaraan antara laki-laki dan perempuan. Perbedaan biologis tidak berarti ketidaksetaraan dalam status jenis kelamin. Fungsi-fungsi biologis harus dibedakan dari fungsi-fungsi sosial.

\section{Pengarusutamaan Gender dalam Pendidikan Islam di Luar Negeri}

1. Pendidikan Islam di Arab Saudi

Berbicara mengenai kondisi perempuan di Arab Saudi erat kaitannya dengan ideologi negara serta konsep tentang domestifikasi perempuan, yang mana hal tersebut dibatasi dengan interpretasi agama yang selektif dan tradisional, sehingga mereka tidak mudah mengenyam pendidikan khususnya bagi mereka yang berada di daerah yang jauh dari akses lembaga pendidikan. Tujuan pendidikan di Arab Saudi adalah sukses menjadi ibu rumah tangga dan ibu yang baik sesuai dengan sifat alamiah mereka seperti mengajar, merawat, atau memberikan praktik medis. ${ }^{21} \mathrm{Hal}$ yang sama juga diungkapkan oleh Haifa A. Jawad, bahwa pada pendidikan dasar, kebanyakan perempuan belajar materi yang dianggap sesuai dengan aturan tradisional masayarakat Arab Saudi. Materi tersebut berkaitan dengan bahasa Arab, ekonomi keluarga, merawat anak, dan aturan agama. ${ }^{22}$

Pendidikan perempuan di Arab Saudi semakin meningkat, hal ini berdasarkan pada data tentang review pendidikan tinggi perempuan di Arab Saudi ke luar negeri 3.879 pada tahun 2004/2005 hingga 35.700 pada tahun 2011/2012.23 Walaupun peningkatan perempuan dalam mengeyam pendidikan terus meningkat, namun pada aspek akses pendidikan bagi perempuan khususnya yang berada di daerah-daerah yang mana Universitas terbatas merupakan bagian dari hambatan yang dihadapi perempuan, keculai bagi mereka yang berada di daerah utama seperti Riyadh, Jeddah dan Dammam.

Proses pembelajaran pada pendidikan perempuan di Arab Saudi telah memanfaatkan teknologi canggih seperti fasilitas internet, di mana para pelajar perempuan dapat menggunakan internet sebagai fasilitas belajar dengan Guru laki-laki via online. Sedangkan metode pembelajarannya sejak 2007 telah mengadopsi sistem pendidikan modern, seperti metode activelearning, team work, dan lain sebagainya. Hal ini menunjukkan adanya

21 Yahya Alhareth, Ibtisam al Dighrir, and Yasra Alhareth, "Review of Women's Higher Education in Saudi Arabia; Science and Education Publishing from Scientific Research to Knowledge", dalam http://pubs.sciepub.com. Diakses pada 9 September 2017.

22 Haifa A. Jawad, The Rights of Women in Islam: An Authentic Approach (New York: St. Martin's Press, Inc.), 27.

${ }^{23}$ Alhareth, Al Dighrir, and Alhareth, "Review of Women's Higher Education in Saudi Arabia”.

Jurnal Pendidikan Agama Islam (Journal of Islamic Education Studies)

Volume 5 Nomor 2 (2017)

ISSN(p) 2089-1946\& ISSN(e) 2527-4511

Hal. 272 - 287 
kemajuan, mengingat metode pembelajaran yang lama di Arab Saudi menggunakan metode hafalan, dan mengulang apa yang dibacakan oleh guru. $^{24}$ Mengenai pengarusutamaan gender dalam bidang pendidikan, Pendidikan Tinggi untuk perempuan pertama kali di Riyadh (1962) dan kemudian disusul oleh Universitas King Abdul Azis (1967) di Jeddah, dan hingga saat ini ada 24 universitas yang menerima mahasiswa (perempuan).

Indeks pembangunan manusia dan pembangunan Gender di Arab Saudi dapat dilihat pada tabel berikut:

Tabel:

Gender Inequality Index 2015

\begin{tabular}{|c|c|c|c|c|c|}
\hline \multirow[t]{2}{*}{$\begin{array}{l}\mathrm{N} \\
\mathrm{o} .\end{array}$} & \multirow[t]{2}{*}{$\begin{array}{c}\text { Negara } \\
\text { Mayoritas } \\
\text { Muslim }\end{array}$} & \multirow[t]{2}{*}{$\begin{array}{c}\text { Gender } \\
\text { Inequalit } \\
\text { y Index }\end{array}$} & \multirow{2}{*}{$\begin{array}{c}\text { Gender Development } \\
\text { Index } \\
\text { (Index } \\
\text { pembangunan } \\
\text { gender) }\end{array}$} & \multicolumn{2}{|c|}{$\begin{array}{c}\text { Human } \\
\text { Development } \\
\text { Index (HDI) }\end{array}$} \\
\hline & & & & $\begin{array}{c}\text { Femal } \\
\mathrm{e}\end{array}$ & Male \\
\hline 1. & Qatar & 0.524 & & 0.853 & $\begin{array}{l}0.85 \\
4\end{array}$ \\
\hline 2. & Saudi Arabia & 0.284 & 0.901 & 0.778 & $\begin{array}{l}0.86 \\
4\end{array}$ \\
\hline 3. & Iran & 0.515 & 0.858 & 0.689 & $\begin{array}{l}0.80 \\
4\end{array}$ \\
\hline 4. & Turki & 0.359 & 0.902 & 0.716 & $\begin{array}{l}0.79 \\
3\end{array}$ \\
\hline 5. & Mesir & 0.573 & 0.868 & 0.633 & $\begin{array}{l}0.72 \\
9\end{array}$ \\
\hline 6. & Yaman & 0.744 & 0.739 & 0.414 & $\begin{array}{l}0.56 \\
0\end{array}$ \\
\hline
\end{tabular}

Sumber: UNDP Report

${ }^{24}$ Alhareth, Al Dighrir, and Alhareth, "Review of Women's Higher Education in Saudi Arabia". 
2. Pendidikan Islam di Mesir

Secara historis gerakan feminisme di Mesir yang tumbuh sebagai gerakan nasional tidak terlepas dari beberapa tokoh perempuan yang berasal dari berbagai kalangan, seperti Bahithat al-Badiyah yang berasal dari kelas atas, dan Musa Nabawiyyah dari strata menengah yang menuntut hak perempuan dalam ruang publik. ${ }^{25}$ Sejak 1923 beberapa tuntutan yang utamanya adalah pendidikan untuk perempuan yang selanjutnya diikuti dengan kesempatan kerja serta status hukum seseorang.

Pendidikan bagi perempuan di Mesir menjadi proyek nasional yang mana gagasan mendidik perempuan adalah mendidik bangsa. Lebih jauh dijelaskan bahwa kurikulum di sekolah perempuan berbeda dengan kurikulum di sekolah laki-laki; kurikulum di sekolah perempuan untuk mempersiapkan perempuan untuk kehidupan mereka sebagai istri, ibu, dan penjaga rumah. Hal tersebut sebagaimana ditulis oleh Nabawiyah Musa yang berjudul al-Mar'a wa al-'Amal (The Women and Work) bahwa laki-laki dan perempuan mempelajari kurikulum akademik yang sama, tetapi perempuan menerima tambahan materi domestik.

Hal tersebut menjadi perdebatan nasional pada pendidikan perempuan sebagai istri dan ibu masa depan. Namun akhir-akhir ini sekolah perempuan di Mesir mengacu pada Barat yang mana kurikulumnya merujuk pada model Inggris. ${ }^{26}$

3. Pendidikan Islam di Malaysia

Berdasarkan HDI dan Gender Inequality Index serta Gender Development Index, Malaysia termasuk negara yang indeks pengembangan manusia antara laki-laki dan perempuan tidak memiliki perbedaan yang sangat jauh, yakni perempuan (0.753), sedangkan laki-laki (0.795). Sedangkan tingkat ketidaksetaran gendernya terendah kedua setelah Singapura dengan index 0.209.27 Sementara ranking GII Malaysia berada pada 42 dari 188 Negara. Hal ini menunjukkan Malaysia mampu menekan ketidaksetaraan gender yang dibuktikan dengan peringkat yang diperolehnya.

Index ketidaksetaraan gender dalam bidang pendidikan di Malaysia semakin rendah, bahkan sejak 1990 peserta didik pada tingkat dasar,

25 Deniz Kandiyoti, Women, Islam \& the State (Philadelpia: Temple University Press, 1991), 205.

26 Margot Badran, Feminists, Islam and Nation; Gender and Making of Modern Egypt (Chichester, West Sussex: Princeton University Press), 63-64.

27 UNDP, "Human Development Index Report, Gender Inequality Index 2014".

Jurnal Pendidikan Agama Islam (Journal of Islamic Education Studies)

Volume 5 Nomor 2 (2017)

ISSN(p) 2089-1946\& ISSN(e) 2527-4511

Hal. 274 - 287 
Telaah Komparatif Pengarusutamaan Gender dalam Pendidikan Islam

menengah dan atas, perempuan lebih tinggi dibanding laki-laki sebagaimana pada tabel berikut: ${ }^{28}$

\begin{tabular}{|c|c|c|c|c|c|c|c|c|}
\hline Combined & \multicolumn{2}{|c|}{1980} & \multicolumn{2}{|c|}{1990} & \multicolumn{2}{|c|}{2000} & \multicolumn{2}{|c|}{2004} \\
\hline gross & Female & Male & Female & Male & Female & Male & Female & Male \\
\hline $\begin{array}{c}\text { ratio } \\
\text { (primary, } \\
\text { secondary, } \\
\text { and tertiary }\end{array}$ & 53.0 & 56.9 & 64.1 & 64.0 & 65.3 & 64.3 & 67.2 & 65.7 \\
\hline
\end{tabular}

Sumber: Measuring And Monitoring Gender Equality Malaysia's Gender Gap Index

Data di atas menunjukkan peningkatan yang signifikan dalam keterlibatan perempuan di bidang pendidikan. Keseriusan negara sebagai pemegang otoritas tertinggi di Malaysia dapat dilihat dalam usahanya untuk menekan ketidaksetaraan dengan membentuk Komite Kabinet dalam Kesetaraan Gender (Cabinet Committee on Gender Equality) pada tahun 2004. Sedangkan pada laporan Ministry of Women, Family and Community Development (MWFCD) yang berkolaborasi dengan The United Nations Development Programme (UNDP) tahun 2014 lebih menekankan fokusnya pada aspek lapangan kerja perempuan Malaysia.

Perempuan di Malaysia hanya sedikit kehilangan kesempatan dengan laki-laki. Sedangkan mengacu pada penelitian Latifah Ismail yang melakukan penelitiannya di Universitas Malaysia bahwa perempuan di Universitas Malaysia memiliki nilai akademik (capaian belajar) lebih tinggi dari laki-laki. ${ }^{29}$ Hasil temuannya menunjukkan bahwa pelajar perempuan (mahasiswi) memiliki ciri-ciri rajin, inspirasi tinggi. Perbandingan jumlah komposisi yang didominasi oleh peserta didik laki-laki terhadap perempuan hanya pada level pendidikan dasar (primary school) sedangkan pada level secondary dan post secondary bahkan hingga perguruan tinggi jumlah perempuan jauh lebih banyak dibanding laki-laki. Dengan demikian, perempuan memiliki peran signifikan dalam pembangunan di Malaysia. Walaupun dalam pemilihan jurusan masih terdapat perbedaan yang signifikan pada jurusan teknik yang didominasi oleh laki-laki.

${ }_{28}$ Measuring And Monitoring Gender Equality Malaysia's Gender Gap Index (Kuala Lumpur: Ministry of Women, Family and Community Development, 2007), 13.

${ }^{29}$ Latifah Ismail, Factors Influencing Gender Gap In Higher Education of Malaysia: A University of Malaya Sample (Kuala Lumpur: Faculty of Education, University of Malaya), 2. 


\section{Pengarusutamaan Gender dalam Pendidikan Islam di Indonesia}

Berdasarkan data pada UNDP gender report, Indonesia memiliki Gender Index Inequality 0.494, yang artinya perempuan kehilangan lebih banyak daripada laki-laki. Termasuk pula perbedaan indeks pengembangan manusia; yang laki-laki 0.706, sedangkan perempuan 0.655. ${ }^{30}$ Berdasarkan data tersebut, pengarusutamaan gender (PUG) menjadi perhatian pemerintah dalam mengembangkan sumber daya manusia bangsa Indonesia. Regulasi yang telah ditetapkan menunjukkan keseriusan pemerintah dalam masalah ketidaksetaraan gender ini.

Mengacu pada Undang-undang Republik Indonesia Nomor 7 tahun 1984 tentang Pengesahan Konvensi Mengenai Penghapusan Segala Bentuk Diskriminasi terhadap Wanita (Convention on the Ellimination of all forms of Discrimination Against Women) yang dalam penjelasannya disebutkan bahwa isi konvensi tersebut sesuai dengan Undang-Undang Dasar 1945 yang menetapkan bahwa "semua warga negara bersamaan dengan kedudukannya dalam hukum dan pemerintahan". Hal ini selaras karena perundang-undangan menganut azas persamaan antara pria dan wanita. ${ }^{31}$ Selanjutnya dalam Instruksi Presiden No.9 tahun 2000 tentang Pengarusutamaan Gender dalam Pembangunan Nasional yang pada lampirannya dijelaskan bahwa "pengarusutamaan gender adalah strategi yang dibangun untuk mengintegrasikan gender menjadi satu dimensi integral dari perencanaan, penyusunan, pelaksanaan, pemantauan, dan evaluasi atas kebijakan dan program pembangunan nasional. ${ }^{32}$ Payung hukum di atas menjadi bagian dari upaya strategis serta sistematis yang dilakukan pemerintah demi menciptakan kesetaraan dan keadilan gender pada seluruh sektor pemerintahan hingga hierarki yang paling dekat secara demografis dengan masyarakat, yakni Bupati/ Walikota.

Parameter keberhasilan pembangunan dewasa ini dilihat dari index pembangunan manusia (IPM) yang salah satu indikatornya adalah indeks pembangunan gender (IPG) yang meliputi aspek kesehatan, ekonomi, pendidikan dan juga politik, perkembangan tersebut sebagaimana tabel berikut ini:

\footnotetext{
30 UNDP, "Human Development Index Report, Gender Inequality Index 2014".

${ }^{31}$ Kelompok Kerja Convention Watch, Hak Azasi Perempuan; Instrumen Hukum untuk Mewujudkan Keadilan Gender (Jakarta: Yayasan Obor Indonesia, 2007), 6.

32 Kelompok Kerja Convention Watch, Hak Azasi Perempuan, 309.

Jurnal Pendidikan Agama Islam (Journal of Islamic Education Studies)

Volume 5 Nomor 2 (2017)

ISSN(p) 2089-1946\& ISSN(e) 2527-4511
}

Hal. 276 - 287 
Telaah Komparatif Pengarusutamaan Gender dalam Pendidikan Islam

Table:

Gender Inequality Index 2015

\begin{tabular}{|c|c|c|c|c|c|}
\hline \multirow[t]{2}{*}{ No. } & \multirow[t]{2}{*}{$\begin{array}{c}\text { Negara } \\
\text { Tetangga }\end{array}$} & \multirow{2}{*}{$\begin{array}{c}\text { Gender } \\
\text { Inequality } \\
\text { Index (Indeks } \\
\text { ketidaksetara } \\
\text { an Gender) } \\
(2014)\end{array}$} & \multirow{2}{*}{$\begin{array}{c}\text { Gender } \\
\text { Development } \\
\text { Index } \\
\text { (Index } \\
\text { pembangunan } \\
\text { gender) } \\
\text { (2014) }\end{array}$} & \multicolumn{2}{|c|}{$\begin{array}{c}\text { Human } \\
\text { Development } \\
\text { Index (HDI) } \\
\text { (2014) }\end{array}$} \\
\hline & & & & Female & Male \\
\hline 1. & Singapura & 0.088 & 0.985 & 0.898 & 0.912 \\
\hline 2. & Malaysia & 0.209 & 0.947 & 0.753 & 0.795 \\
\hline 3. & Thailand & 0.380 & 1.000 & 0.726 & 0.726 \\
\hline 4. & Indonesia & 0.494 & 0.927 & 0.655 & 0.706 \\
\hline 5. & Filipina & 0.420 & 0.977 & 0.649 & 0.664 \\
\hline
\end{tabular}

Sumber: UNDP Report

Paparan data di atas, menunjukkan bahwa perempuan di Indonesia kehilangan kesempatan dibanding laki-laki tertinggi dibanding dengan negaranegara tetangga lain seperti Malaysia, Thailand, Filipina. Demikian pula dalam index pengembangan gender berada pada tingkat paling rendah yakni 0.927 . Kondisi ini mempengaruhi pembangunan Indonesia, di mana perempuan juga bagian dari warga negara yang harus diberdayakan serta memiliki akses yang sama, khususnya dalam bidang pendidikan.

Pembangunan saat ini diarahkan pada pengembangan kebijakan, program, dan proyek yang secara khusus dirancang untuk mengangkat kesetaraan gender terutama kaum perempuan. Dengan demikian, perlu adanya penelaahan konsep yang mendasari pendekatan kebijakan ini. Sebagaimana ditulis oleh Elly M. Setiadi dan Usman Kolip tentang pendekatan-pendekatan pembangunan di antaranya adalah: ${ }^{33}$

1. Pendekatan Kesejahteraan

Ada tiga asumsi yang mendasari pendekatan ini: a. Perempuan dianggap sebagai penerima pasif bukan dianggap sebagai subjek dalam pembangunan; b. Peran pengasuhan dianggap penting bagi perempuan di

33 Elly M. Setiadi dan Usman Kolip, Pengantar Sosiologi Pemahaman Fakta dan Gejala Permasalahan Sosial; Teori, Aplikasi dan Pemecahannya (Jakarta: Kencana, 2011), 902. 
dalam masyarakat; dan c. Mengasuh anak merupakan peran yang paling penting bagi perempuan dalam semua aspek pembangunan ekonomi. Pendekatan ini berorientasi pada keluarga yang berpusat pada perempuan dalam peran reproduktif, dan mengasumsikan laki-laki memiliki peran produktif, dan hubungan ibu dan anak sebagai pusat perhatian. Implementasi pendekatan ini diwujudkan dalam bentuk pemberian bantuan keterampilan pada perempuan sebagai jalan untuk meningkatkan kesejahteraan keluarga. Dengan demikian, pendekatan ini lebih memahami perempuan sebagai persoalan, bukan sebagai sumber daya yang produktif, sehingga dampakdampak dari pendekatan ini justru berakibat pada ketergantungan perempuan pada pihak lain dan tidak menciptakan kemandirian perempuan. Selain itu, pendekatan ini justru menimbulkan asumsi mengesampingkan peran perempuan dalam pembangunan.

2. Pendekatan Keadilan

Pendekatan ini berangkat dari ketidakadilan antara laki-laki dan perempuan, baik dalam kehidupan publik, pribadi, maupun dalam kelompokkelompok sosial ekonomi. Asal-usul subordinasi kaum perempuan tidak hanya dalam konteks keluarga, tetapi juga dalam hubungan antara laki-laki dan perempuan di lokasi pasar, sehingga pendekatan ini mementingkan kemandirian ekonomi sebagai wujud keadilan. ${ }^{34}$ Pendekatan ini berusaha mengurangi ketidakadilan antara laki-laki dan perempuan, terutama dalam pembagian kerja secara seksual dan dalam pemenuhan kebutuhan strategis gender yang diidentifikasikan dalam bentuk persaman hak.

3. Pendekatan Anti-Kemiskinan

Pendekatan ini bukan berkaitan dengan subordinasi perempuan tetapi lebih terfokus pada kemiskinan, sehingga upaya yang ditempuh adalah mengurangi ketidaksamaan pendapatan. Pusat perhatiannya adalah anti kemiskinan. Asumsi ini didasarkan pada anggapan bahwa pengentasan kemiskinan dan pertumbuhan ekonomi yang imbang memerlukan peningkatan produktivitas perempuan di rumah tangga berpenghasilan rendah. Akar dari kemiskinan perempuan dan ketimpangannya dengan kaum laki-laki adalah akibat dari lemahnya kepemilikan tanah dan kepemilikan modal secara pribadi, dan diskriminasi seksual pada pasar kerja. Oleh sebab itu, perlu adanya kebebasan untuk memperoleh kesempatan kerja dan peningkatan penghasilan di kalangan perempuan kelas bawah dengan membuka akses terhadap sumber-sumber ekonomi. Perhatian utama pendekatan ini adalah pada kebutuhan strategis, terutama pada program

34 Setiadi dan Kolip, Pengantar Sosiologi Pemahaman Fakta dan Gejala Permasalahan Sosial, 903. 
keluarga berencana untuk mengurangi kelahiran, program pendidikan, dan ketenagakerjaan.

4. Pendekatan Efisiensi

Pendekatan ini dilatarbelakangi oleh asumsi bahwa peningkatan partisipasi ekonomi perempuan di negara-negara dunia ketiga secara otomatis dan akan berdampak pada terciptanya keadilan dan kesetaraan gender. Di dalam proses pembangunan, sumber daya perempuan yang ada tampak seolah-olah disia-siakan atau kurang dimanfaatkan secara maksimal.

5. Pendekatan Penguatan Diri

Pendekatan ini didasari oleh asumsi dasar yang berhubungan dengan kekuasaan dan pembangunan yang mendasari pendekatan-pendekatan sebelumnya. Selain itu, mengindikasikan kekuasaan dalam rangka meningkatkan kemandirian dan kekuatan internal perempuan. Pendekatan ini tidak menekankan pada status perempuan secara relatif terhadap laki-laki, seperti pendekatan keadilan, tetapi berusaha memberikan kekuasaan kepada perempuan melalui pendistribusian kembali kekuasaan di dalam dan di antara masyarakat.

Pendekatan-pendekatan di atas merupakan bagian dari usaha untuk mewujudkan kesetaraan gender dalam berbagai aspek. Yang mana jika dianalisis bahwa pendekatan-pendekatan tersebut memiliki keterkaitan dengan pendidikan, di mana semakin baik pendidikan perempuan Indonesia, maka akan semakin menambah wawasan, meningkatkan daya berfikir kritis, kreatif, serta inovatif, sehingga mendapatkan ruang pada sektor pekerjaan yang lebih baik, yang dapat membantu kesejahteraan keluarga bahkan meningkatkan ekonomi bangsa. Dengan demikian, pembangunan manusia Indonesia akan semakin baik dan dapat berkompetisi dengan negara lain.

Keseriusan pemerintah Indonesia di antaranya dapat dilihat dari regulasi yang memfokuskan pada pengarusutamaan gender pada sektor pendidikan. Hal ini tampak pada tahun 2010, Menteri Negara Pemberdayaan Perempuan dan Perlindungan Anak Republik Indonesia menetapkan Peraturan Menteri Negara Pemberdayaan Perempuan dan Perlindungan Anak Republik Indonesia Nomor 11 Tahun 2010 tentang Pedoman Pelaksanaan Pengarusutamaan Gender di Madrasah Kementerian Agama Republik Indonesia. ${ }^{35}$ Hal ini berdasarkan pada pemetaan situasi, kondisi serta proses pembelajaran serta partisipasi

35 Peraturan Menteri Negara Pemberdayaan Perempuan dan Perlindungan Anak Republik Indonesia Nomor 11 Tahun 2010 tentang Pedoman Pelaksanaan Pengarusutamaan Gender di Madrasah Kementerian Agama Republik Indonesia. 
masyarakat masih ada kesenjangan gender, sehingga perlu adanya pengarusutamaan gender di lingkungan madrasah.

Regulasi ini sangat strategis dalam meminimalisir kesenjangan gender, dijadikan analisis mengapa kesenjangan pendidikan ini terjadi. Sebagaimana ditulis oleh Eko: ${ }^{36}$ Pertama, persepsi masyarakat tentang anak perempuan. Dibandingkan dengan anak laki-laki, anak perempuan tidak diuntungkan secara kultur. Pada umumnya masyarakat beranggapan bahwa laki-laki adalah penopang ekonomi keluarga, untuk itu pendidikan bagi anak laki-laki merupakan suatu keharusan untuk dicapai, karena dengan semakin tinggi pendidikan anak laki-laki diharapkan mendapatkan pekerjaan yang sesuai dengan pendidikannya. Anak laki-laki oleh sebagian besar masyarakat masih dianggap sebagai sarana mencari nafkah. Sementara itu nilai-nilai yang diberlakukan pada anak perempuan didasarkan pada anggapan bahwa perempuan yang baik adalah perempuan yang bisa menjadi ibu rumah tangga yang baik. Dalam konteks itu, masyarakat kurang memberi toleransi kepada anak perempuan untuk mengenyam pendidikan yang lebih tinggi, karena pada akhirnya anak perempuan harus kembali ke rumah menjadi ibu rumah tangga.

Kedua, orientasi pendidikan tidak melihat aspek perbedaan gender sebagai variabel utama kebijakan. Kebijakan pendidikan lebih ditujukan kepada masyarakat secara umum tanpa membeda-bedakan jenis kelamin. Orientasi pendidikan semacam itu boleh saja, namun orientasi itu mengesampingkan kaum perempuan yang secara kultur belum cukup baik untuk mengenal sekolah dalam kehidupannya. Dalam konteks ini, perempuan yang secara kultur tidak diberi ruang, secara struktur kebijakan negara tidak dapat mendorong secara khusus anak perempuan untuk melakukan aktivitas sekolah. Ketiga, akses pendidikan yang dikeluarkan oleh pemerintah kurang menjangkau masyarakat yang berada di pedalaman. Dalam situasi yang serba kekurangan dan secara akses juga sulit maka pilihan bagi sejumlah keluarga tertuju pada pilihan untuk membuat anak perempuannya bekerja dibandingkan harus sekolah yang justru mengeluarkan biaya yang semakin berat ditanggung.

Data Badan Pusat Statistik menunjukkan bahwa perempuan dalam bidang pendidikan masih mengalami kesenjangan. Di perkotaan, pada tahun 2013 laki-laki yang menamatkan pada jenjang perguruan tinggi $10,64,37$ perempuan 10,47. Sedangkan di pedesaan laki-laki 2,94 dan perempuan 3,29. Namun untuk tingkat SMA sederajat, di perkotaan, laki-laki 37,10, perempuan

36 Eko Bambang Subiyantoro, "Sensitivitas Gender Kebijakan Pemerintahan Sby", dalam www.theindonesianinstitute.com, Diakses pada 15 September 2017.

37 BPS RI, SUSENAS 2009-2011, dalam http://www.bps.go.id. Diakses pada 15 September 2017. 
29,99. Di pedesaan, laki-laki 17,47 dan perempuan 12,86. Pada level internasional, Indonesia menduduki peringkat 110 dalam aspek ketimpangan gender dari seluruh negara yang tercantum pada data Human Developmen Report pada tabel Gender Inequaliy Index (GII) tahun 2014. Artinya, upaya sistematis dalam menumbuhkan kesadaran akan kesetaraan gender pada berbagai lapisan serta melalui lembaga formal, informal dan non formal perlu ditingkatkan agar ketimpangan gender semakin menurun. Karena pada hakikatnya manusia adalah equal (setara).

\section{E. Analisis Komparatif Pengarusutamaan Gender dalam Pendidikan Islam}

Pembahasan mengenai perbandingan pendidikan bagi perempuan di beberapa negara yakni Saudi Arabia, Mesir, dengan Indonesia, memiliki persamaan dalam konstruksi sosiokultur, di mana pengaruh interpretasi keagamaan yang dijadikan instrumen legitimasi superioritas laki-laki sangat tampak. Hal ini mempengaruhi ruang gerak perempuan pada wilayah publik, termasuk hak untuk meraih pendidikan yang lebih tinggi. Hal itu mulanya tidak hanya terjadi pada negara yang penduduknya Muslim, terlihat dari gerakan kaum feminis gelombang pertama yang tuntutan tersebut bahkan dimulai oleh Mary Wollstonecraft yang kemudian secara kongkret Mary mendirikan sekolah khusus untuk perempuan di Newington Green, London bagian Utara. Sedangkan hal yang sama juga dilakukan oleh Bahithat al-Badiyah dan Musa Nabawiyyah yang bahkan mendedikasikan dirinya sebagai pendidik, yang merupakan bagian dari upaya agar perempuan Mesir terdidik serta memiliki akses pada ruang publik. Di Indonesia pun menorehkan sejarah yang sama, R.A Kartini, yang harus berusaha mendapatkan pendidikan yang setara.

Domistifikasi perempuan nampaknya menjadi permasalahan yang juga merambat pada akses perempuan di bidang pendidikan. Selain hal di atas, paradigma masyarakat yang menganggap bahwa jurusan yang sesuai dengan naluri perempuan seperti pada jurusan bahasa, pendidikan, keperawatan, ilmuilmu sosial menjadi halangan bagi perempuan yang memiliki potensi di bidang teknik misalnya. Kondisi ini juga melanda Malaysia, di mana pada jurusan teknik, hanya sedikit diminati perempuan.

Dari kondisi tersebut, maka pendidikan Islam merupakan entitas penting yang secara sistematis-metodologis dapat dijadikan instrumen dalam mewujudkan kesetaraan. Termasuk pula dalam menghasilkan ulama-ulama perempuan. Musdah Mulia, menguraikan beberapa upaya yang dapat 
dilakukan: ${ }^{38}$ Pertama, seluruh peraturan dan perundang-undangan yang berkaitan dengan pendidikan baik pada tingkat nasional maupun daerah, harus dipastikan memihak atau paling tidak memberikan kesempatan seluas-luasnya kepada perempuan. Bukan hanya akses dalam semua level pendidikan, melainkan juga menjamin adanya kesetaraan dalam segenap output pendidikan.

Kedua, perbaikan dalam sistem administrasi dengan menggunakan analisis gender. Reformasi dalam sistem administrasi sangat diperlukan, misalnya, dengan meningkatkan jumlah perempuan dalam berbagai posisi dan jabatan strategis di bidang operasional pendidikan, seperti kepala sekolah, kepala tata usaha dan pengawas pendidikan. Ketiga, perbaikan dalam sistem kurikulum yang menjamin terwujudnya content pendidikan yang berperspektif gender dan terbangunnya kesadaran akan pentingnya pemenuhan hak-hak perempuan, terutama hak-hak reproduksi.

Keempat, penyempurnaan bahan-bahan pendidikan dengan menggunakan perspektif keadilan dan kesetaraan gender. Melakukan revisi terhadap buku-buku yang bias gender. Hal ini masih sering ditemukan pada materi-materi pelajaran yang memvisualisasikan perempuan pada posisi inferior. Padahal seharusnya materi yang diajarkan berdasarkan pada nilai-nilai keadilan, kesetaraan, dan kemanusiaan yang memposisikan manusia laki-laki dan perempuan dalam posisi sentral sebagai subjek pendidikan. Kelima, peningkatan kualitas pendidik. Laki-laki dan perempuan yang peka dan sadar gender. Keenam, perlunya memperbaiki sistem pengkaderan ulama yang digelar MUI dan lembaga-lembaga Pendidikan Islam lainnya termasuk materi dan sistem seleksinya, sehingga responsif dengan tuntunan keadialan gender, dan juga mempertimbangkan kepentingan dan partisipasi perempuan. ${ }^{39}$

Pengarusutamaan gender dalam bidang pendidikan meliputi membuat sekolah lebih mudah diakses, memperpendek jarak ke sekolah, terutama akan mendorong anak-anak perempuan agar bersekolah. Resiko keamanan dan reputasi sosial menjadi berkurang apabila lokasi sekolah dekat dengan lokasi komunitas. Pastikan fasilitas WC yang terpisah dan tertutup tersedia. Menigkatkan kualitas guru dan naikkan jumlah guru perempuan. Tetapkan kuota minimum guru perempuan. Oleh karena hanya sedikit perempuan yang dapat memenuhi persyaratan standar pengajaran, maka penting sekali untuk melakukan perekrutan lokal secara aktif, khususnya di wilayah pedesaan. Dengan membawa pelatihan ke lokasi yang dekat dengan komunitas akan menarik kaum perempuan yang semula tidak tertarik untuk mengajar karena

\footnotetext{
38 Musdah Mulia, Muslim Reformis: Perempuan Pembaru Keagamaan (Bandung: Mizan Pustaka, 2005), 122.

${ }^{39}$ Mulia, Muslim Reformis, 23.

Jurnal Pendidikan Agama Islam (Journal of Islamic Education Studies)

Volume 5 Nomor 2 (2017)

ISSN(p) 2089-1946\& ISSN(e) 2527-4511

Hal. 282 - 287
} 
kendala budaya atas mobilitas perempuan, ketiadaan rumah, atau karena tanggung jawab keluarga. ${ }^{40}$

Sebagaimana ditulis oleh Rukmina, ${ }^{41}$ upaya untuk mengatasi bias gender dalam pendidikan Islam di antaranya sebagai berikut: Pertama, reinterpretasi ayat-ayat al-Qur'an dan hadith yang bias gender, dilakukan secara kontinu agar ajaran agama tidak dijadikan justifikasi sebagai kambing hitam untuk memenuhi keinginan segelintir orang. Kedua, muatan kurikulum nasional yang menghilangkan dikhotomis antara laki-laki dan perempuan, demikian pula kurikulum lokal dengan berbasis kesetaraan, keadilan, dan keseimbangan. Kurikulum disusun sesuai dengan kebutuhan dan tipologi daerah, yang dimulai dari tingkat pendidikan taman kanak-kanak sampai ke tingkat perguruan tinggi.

Ketiga, pemberdayaan kaum perempuan di sektor pendidikan informal seperti pemberian fasilitas belajar mulai di tingkat kelurahan sampai kepada tingkat Kabupaten/ Kota dan disesuaikan dengan kebutuhan daerah. Keempat, pemberdayaan di sektor ekonomi untuk meningkatkan pendapatan keluarga terutama dalam kegiatan industri rumah tangga (home industry), dengan demikian perlahan-lahan akan menghilangkan ketergantungan ekonomi kepada laki-laki. Karena salah satu terjadinya marginalisasi pada perempuan adalah ketergantungan ekonomi keluarga kepada laki-laki.

Kelima, pendidikan politik bagi perempuan agar dilakukan secara intensif untuk melek politik bagi kaum perempuan. Karena masih ada anggapan bahwa politik itu hanya milik laki-laki, dan politik itu adalah kekerasan, padahal sebaliknya politik adalah seni untuk mencapai kekuasaan. Dengan demikian kuota 30\% sesuai dengan amanah Undang-Undang segara terpenuhi, mengingat pemilih terbanyak adalah perempuan. Keenam, pemberdayaan di sektor ketrampilan (skill) baik ketrampilan untuk kebutuhan rumah tangga, maupun yang memiliki nilai jual ditingkatkan terutama kaum perempuan di pedesaan agar terjadi keseimbangan antara perempuan yang tinggal di perkotaan dengan pedesaan sama-sama memiliki ketrampilan yang relatif bagus. Ketujuh, sosialisasi Undang-Undang Anti Kekerasan dalam Rumah tangga lebih intens dilakukan agar kaum perempuan mengetahui hak dan kewajiban yang harus dilakukan sesuai dengan amanah dari UU KDRT.

Pengarusutamaan gender merupakan bagian dari strategi pembangunan manusia yang terkorelasi dengan pendidikan. Khususnya pendidikan Islam yang

40 Dina Hermina, "Strategi Pelaksanaan Pengarusutamaan Gender (PUG) dalam Pendidikan," Mu'adalah: Jurnal Studi Gender dan Anak, Vol. 2, No. 1, Januari-Juni 2014,11

41 Gonibala Rukmina, "Fenomena Bias Gender dalam Pendidikan Islam," Iqra, Vol. 4 (Juli Desember 2007), 42. 
menjadi perhatian oleh Menteri Negara Pemberdayaan Perempuan dan Perlindungan Anak Republik Indonesia yang menetapkan Peraturan Menteri Negara Pemberdayaan Perempuan dan Perlindungan Anak Republik Indonesia Nomor 11 Tahun 2010 tentang Pedoman Pelaksanaan Pengarusutamaan Gender di Madrasah Kementerian Agama Republik Indonesia. Hal ini berdasarkan pada pemetaan situasi, kondisi serta proses pembelajaran serta partisipasi masyarakat yang masih mengalami kesenjangan gender, sehingga perlu adanya pengarusutamaan gender di lingkungan madrasah dan lembaga pendidikan Islam yang lain.

\section{F. Kesimpulan}

Pengarusutamaan gender ditinjau dari perspektif perbandingan pendidikan bagi perempuan di beberapa negara, yakni Saudi Arabia, Mesir, Malaysia dan Indonesia, kondisinya memiliki persamaan dalam konstruksi sosiokultur, dan pengaruh interpretasi keagamaan dijadikan instrumen legitimasi bagi superioritas laki-laki. Hal ini mempengaruhi ruang gerak perempuan pada wilayah publik, termasuk hak untuk meraih pendidikan yang lebih tinggi. Pada awalnya, di beberapa negara di Asia dan Afrika masih terjadi domestifikasi dan subordinasi pada perempuan, yang mana hal tersebut dibatasi dengan interpretasi agama yang selektif dan tradisional, sehingga mereka tidak mudah mengenyam pendidikan. Namun, dalam perkembangannya, terjadi peningkatan dalam keterlibatan perempuan di bidang pendidikan melalui pengarusutamaan gender oleh pemerintah dalam mengembangkan sumber daya manusia di beberapa negara tersebut. Regulasi-regulasi yang telah ditetapkan menunjukkan keseriusan pemerintah dalam masalah ketidaksetaraan gender yang terjadi. Pengarusutamaan gender merupakan bagian dari strategi pembangunan manusia yang terkorelasi dengan pendidikan Islam.

Oleh karena itu, dalam pendidikan Islam, khususnya materi pelajaran, sebaiknya mentransfer nilai-nilai keadilan, kesetaraan, dan juga kemanusiaan yang merupakan bagian dari nilai-nilai universal ajaran Islam. Dalam hal ini seluruh pihak yang terkait dalam institusi pendidikan Islam memiliki sensitifitas terhadap kesenjangan yang terjadi, baik dalam proses pembelajaran, maupun pada buku-buku pelajaran yang bias gender. Hal ini masih sering ditemukan pada materi-materi pelajaran yang memvisualisasikan perempuan pada posisi inferior dan laki-laki pada posisi superior. Termasuk pula dalam kajian teks-teks keagamaan yang dijumpai mengandung interpretasi misogini (membenci perempuan). Hal ini membutuhkan kepekaan serta kesadaran untuk merekonstruksi konteks ketidaksetaraan tersebut. 
Telaah Komparatif Pengarusutamaan Gender dalam Pendidikan Islam

\section{G. Referensi}

Arkoun, Muhammad. Tarikhiyyah Al-Fikr Al-'Araby Al-Islamy, Terj. Hasyim Sholeh. Beirut: Markaz Al-Inma' Al-Qaumi, 1998, Cet III.

Badran, Margot. Feminists, Islam and Nation; Gender and Making of Modern Egypt. Chichester, West Sussex: Princeton University Press, 1996.

Barlas, Asma. Cara Qu'ran Membebaskan Perempuan. Jakarta: Serambi Ilmu Semesta, 2005.

Fennell, Shailaja., and Arnot, Madeleine. Gender Education and Equality in Global Context; Conceptual Framework And Policy Perspective. Routledge: London and New York, 2007.

Gonibala, Rukmina. “Fenomena Bias Gender dalam Pendidikan Islam”, Iqra. Vol. 4 (Juli - Desember 2007).

Hermina, Dina. "Strategi Pelaksanaan Pengarusutamaan Gender (PUG) dalam Pendidikan", Mu'adalah: Jurnal Studi Gender dan Anak. Vol. 2, No. 1, (Januari-Juni 2014).

Ismail, Latifah. Factors Influencing Gender Gap In Higher Education of Malaysia: A University of Malaya Sample. Kuala Lumpur: Faculty of Education, University of Malaya.

Jawad, Haifa A. The Rights of Women in Islam: An Authentic Approach. New York: St. Martin's Press, Inc.

Kandiyoti, Deniz. Women, Islam \& the State. Philadelpia: Temple University Press, 1991.

Kelompok Kerja Convention Watch. Hak Azasi Perempuan; Instrumen Hukum untuk Mewujudkan Keadilan Gender. Jakarta: Yayasan Obor Indonesia, 2007.

Lubis, Akhyar Yusuf. Pemikiran Kritis Kontemporer; Dari Teori Kritis, Culture Studies, Feminisme, Postkolonial Hingga Multikulturalisme. Jakarta: Rajawali Pers, 2015.

Maraghi (al), Ahmad Musthofa. Tafsir al-Maraghi, Juz 4.

Maula, Bani Syarif. "Kepemimpinan dalam Keluarga: Perspektif Fiqh dan Analisis Gender," Musawa; Jurnal Studi Gender dan Islam. Vol. 3, No. 1, (Maret 2004). 
Rohil Zilfa

Ministry of Women, Family and Community Development of Malaysia. Measuring And Monitoring Gender Equality Malaysia's Gender Gap Index. Kuala Lumpur: Ministry of Women, Family and Community Development, 2007.

Muhammad, Husein. Fiqh Perempuan. Yogyakarta: LKiS, 2001.

Mulia, Musdah. Muslim Reformis: Perempuan Pembaru Keagamaan. Bandung: Mizan Pustaka, 2005.

Murata, Sachiko. The Tao of Islam: Kitab Rujukan tentang Relasi Gender dalam Kosmologi dan Teologi Islam, Terj. Rahmani Astuti dan M. S. Nasrullah. Bandung: Mizan, 1996.

Peraturan Menteri Negara Pemberdayaan Perempuan dan Perlindungan Anak Republik Indonesia Nomor 11 Tahun 2010 tentang Pedoman Pelaksanaan Pengarusutamaan Gender di Madrasah Kementerian Agama Republik Indonesia.

Qasi (al), Muhammad Jamaludddin. Tafsir al-Qasi. Darul Kutub al-Ilmiyyah: Beirut, Juz 2.

Rusydiyah, Evi Fatimatur. "Pendidikan Islam dan Kesetaraan Gender (Konsepsi Sosial tentang Keadilan Beerpendidikan dalam Keluarga", Jurnal Pendidikan Agama Islam (Jornal of Islamic Education Studies). Vol. 4 No. 1 (2016).

Setiadi, Elly M., \& Kolip, Usman. Pengantar Sosiologi Pemahaman Fakta dan Gejala Permasalahan Sosial:Teori, Aplikasi dan Pemecahannya. Jakarta: Kencana, 2011.

Subhan, Zaitunah. Tafsir Kebencian: Studi Bias Gender dalam Tafsir Al-Qur'an. Yogyakarta: LKIS, 1999.

Wadud, Amina. Qur'an Menurut Perempuan: Membaca Kembali Kitab Suci dengan Semangat Keadilan. Terj. Abdullah Ali. Jakarta: Serambi Ilmu Semesta, 2006.

Alhareth, Yahya., Dighrir (al), Ibtisam., and Alhareth, Yasra. “Review Of Women's Higher Education In Saudi Arabia, Science and Education Publishing from Scientific Research to Knowledge”, dalam http://pubs.sciepub. com.

BPS RI. “SUSENAS 2009-2011”, dalam http://www.bps.go.id.

Subiyantoro, Eko Bambang. "Sensitivitas Gender Kebijakan Pemerintahan Sby", dalam www.theindonesianinstitute.com. 
Telaah Komparatif Pengarusutamaan Gender dalam Pendidikan Islam

UNDP (Human Development Index Report, Gender Inequality Index), 2014, dalam http://hdr.undp.org.

UNESCO. "Promise Gender Equality - A Global Priority, The Division for Gender Equality", 8, dalam http://www.unesco.org/genderequality.

Jurnal Pendidikan Agama Islam (Journal of Islamic Education Studies)

Volume 5 Nomor 2 (2017)

ISSN(p) 2089-1946 \& ISSN(e) 2527-4511

Hal. 287 - 287 